\title{
Influence of Biofertilizers under Drip Fertigation System on NPK Uptake and Yield Performance of Greengram (Vigna radiata L.)
}

\author{
K. Shravani*, S. Triveni, P. C. Latha, V. Ramulu, M. Tejashree and K. Damodharachari
}

Department of Agricultural Microbiology \& Bioenergy, College of Agriculture, Professor Jayashankar Telangana State Agricultural University, Rajendranagar, Hyderabad-500030, Telangana, India

*Corresponding author

\section{A B S T R A C T}

\section{Keywords}

Liquid biofertilizers, Biofertgation, precision farming system,

Microbial inoculants (Rhizobium and PSB)

Article Info

Accepted: 18 April 2019 Available Online: 10 May 2019
Field experiment was conducted at water technology centre fields, college farm, College of Agriculture, PJTSAU, Rajendranagar, Hyderabad, Telangana during kharif 2016 - 2017 with one of the objective of nutrient uptake and yield performance of Greengram, variety (MGG - 295) under Drip fertigation system. The experiment was laid out in Randomizerd block design with three replications. Use of carrier based inoculum for crop growth and yield is wide practice among the conventional agriculture. Precision farming is a site specific management approach whereas the conventional practice is a uniform fertilizer application. Carrier based inoculum is not suitable for precision farming system due to clogging effect. Hence the liquid bioinoculants viz., Rhizobium and PSB were used under drip fertigation system to evaluate the yield performance and NPK uptake of greengram. The result suggested the positive influence of $100 \%$ RDF of NPK + Rhizobium (LB) and PSB (LB) under drip fertigation the flow rate was $2 \mathrm{lit}^{\mathrm{hr}^{-1}}$ on delivery of microbial inoculants Rhizobium (8.38 log no. of cells ml ${ }^{-1}$ ) and PSB $\left(8.15 \log\right.$ no. of cells $\mathrm{ml}^{-1}$ ) were increased the NPK uptake and $23.93 \%$ yield over conventional method.

\section{Introduction}

The high inputs of chemical fertilizers have not only caused environmental problems but also became a cause of concern for human health. Biofertilizers have been identified to address the issue of excessive use of chemical fertilizers. Biofertilizers are one of the sustainable sources of supplementation to chemical fertilizers for Agriculture. The term Biofertilizers generally are defined as preparation containing live or latent cells of efficient strains of Nitrogen fixing,
Phosphorus solubilizing or cellulolytic microorganisms used for application to seed or soil. It is also playing an important role for supplementing the essential plant nutrients for sustainable agriculture, economy and ecofriendly environment.

Biofertilizers are low cost and economically viable technology which improves plant growth and development. These are reduce the environmental pollution caused by chemical fertilizers, protect plants against many soilborne pathogens and help the plant to grow 
under stress conditions (Brahmaprakash and Sahu, 2012).

Liquid biofertilizers of good quality hold great promise in agriculture because of benefits over the conventional carrier based biofertilizers such as liquid biofertilizers contains special cell protectants or substances that encourage the formation of resting spores or cysts for longer shelf life (Chandra et al., 2005) and protect the cells against seed toxicity after seed application; provide better resistance against abiotic stress, high temperature (up to $55^{\circ} \mathrm{C}$ ), desiccation and osmotic shocks, better survival on seed and better nodulation; cost saving on carrier material such as pulverization, neutralization, sterilization, contamination free and convenience of handling, storage and transportation.

Greengram (Vigna radiate L. Wilczek) is an ancient and well known third most important pulse crop in India, on account of its nutritional quality, early maturing and the suitability in cropping systems. India is a leading green gram cultivator, with up to $55 \%$ of the total world acreage and $45 \%$ of total production (Singh et al., 2013; Rishi et al., 2009). It is one of the most important pulse crop for protein supplement.

Efficient management of water is of outmost importance for sustaining and enhancing Agricultural production (Palanisami et al., 2012). Drip fertigation allows precise timing and uniform distribution of fertilizer nutrients, and is an efficient and agronomically sound method of providing soluble plant nutrients directly to the active plant root zone. Biofertigation is the efficient and precise use of beneficial microorganisms through a microirrigation system. Biofertigation offers vast scope for minimizing the use of chemical fertilizers. There are more chances for increasing the yield, quality, fertilizer-use efficiency, water-use efficiency, and economic output. With drip fertigation and in combination with organics, there is possibility for organic farming to be intensified in the future.

\section{Materials and Methods}

The field experiment was conducted at water technology centre fields, college farm, College of Agriculture, PJTSAU, Rajendranagar, during kharif 2016 - 2017. The location is geographically situated at $17^{\circ} \mathrm{N}$ Latitude and $78^{\circ} \mathrm{E}$ longitude at an altitude of $542.3 \mathrm{~m}$ above MSL. The soil of $n$ experimental site was sandy loam in texture, moderate in organic carbon, low in nitrogen and medium in available phosphorus and high in potash and slightly alkaline $(\mathrm{pH}$ 7.6) in chemical reaction.

The experiment was laid out in a Randomized Block Design with 10 treatment combinations. The treatments are T1: $100 \% \mathrm{RDF}, \mathrm{T} 2: 100$ $\% \mathrm{RDF}+\mathrm{CBBF}$ Seed treatment, T3: $100 \%$ RDF + CBBF Soil treatment, T4: $100 \%$ RDF + LBBF Seed treatment, T5: $100 \% \mathrm{RDF}+$ LBBF Soil treatment, T6: $100 \% \mathrm{RDF}+$ LBBF Drip fertigation, T7: $100 \% \mathrm{RDF}+$ LCBF Seed treatment, T8: $100 \%$ RDF + LCBF Soil treatment, T9: $100 \% \mathrm{RDF}+$ LCBF Drip fertigation, T10 Control: Only biofertilizers. Sowing was done on 15th July, 2016 by hand dibbling two to three seeds at each hill at a recommended spacing of $30 \mathrm{~cm}$ $\times 10 \mathrm{~cm}$. Recommended dose of fertilizer for greengram is 20: 50: $00 \mathrm{~N} \mathrm{P} \mathrm{K} \mathrm{kg} \mathrm{ha}{ }^{-1}$. Fertilizer viz., nitrogen, phosphorus were applied in respective plots as per the recommendation by using the urea and SSP.

Each plot was measured $25.2 \mathrm{~m}^{2}$. The drip lines were arranged for the treatments of $\mathrm{T}_{6}$ (LBBF) \& $\mathrm{T}_{9}$ (LCBF) plots and the drip system was checked for its flow rate. The two drip irrigated plots $\left(\mathrm{T}_{6} \& \mathrm{~T}_{9}\right)$ had six drip line laterals each. The lateral spacing was $0.6 \mathrm{~m}$. 
The flow rate was $2 \mathrm{lph}$ (liters per hour). The two treatments were supplied with an independent fertigation system consist of a drip tubes and controlled tapes. A tank filled with fertigation water was placed $1 \mathrm{~m}$ above the ground to maintain enough water pressure $1 \mathrm{~kg} / \mathrm{cm}^{2}$. Surface irrigation was given as and when cumulative pan evaporation (CPE) value reached the level of $83 \mathrm{~mm}$, which is in accordance with IW/CPE ratio of 0.60 .

The fertilizer solution was prepared by dissolving the required quantity of fertilizer with water in 1:5 ratio and liquid biofertilizers Rhizobium $(10 \mathrm{ml})+$ PSB $(10 \mathrm{ml})$ injected into the irrigation system through venturi assembly. Fertigation interval was scheduled once in 7 days interval. The recommended doses (20: 50: $00 \mathrm{NPK} \mathrm{kg} \mathrm{ha}{ }^{-1}$ ) of inorganic fertilizers i.e., urea $(46 \% \mathrm{~N})$ and single super phosphate $\left(16 \% \mathrm{P}_{2} \mathrm{O}_{5}\right)$ were applied as basal to the surface irrigated treatments except fertigation treatment (T6 \& T9) combinations. Data were collected for greengram nutrient uptake and seed yield and haulm yield at harvest stage. The nutrient content uptake values obtained as percentage in the analysis was multiplied by the respective dry matter content for computing $\mathrm{N}, \mathrm{P}$ and $\mathrm{K}$ uptake expressed in $\mathrm{kg} \mathrm{ha}^{-1}$.

Percentage of nutrient content $x$ Total dry matter production $\left(\mathrm{kg} \mathrm{ha}^{-1}\right)$ Nutrient uptake $\left(\mathrm{kg} \mathrm{ha}^{-1}\right)=$

100

\section{Results and Discussion}

\section{Influence of biofertigation on nutrient uptake by greengram plant}

The data regarding to uptake of NPK (Table 1) was significantly noticed maximum uptake by application of liquid based biofertilizers through drip as fertigation with treatment $\mathrm{T}_{6}$ (100\% RDF + LBBF drip fertigation) when compared to all other treatment combinations. This might be due to excess irrigation in surface irrigation methods, fertilizer nutrients might have been leached beyond the root zone, whereas in drip fertigation, fertilizers were applied through drip irrigation in desired split doses throughout the growing period according to crop requirements, so that the losses were minimized and opportunity was provided to take up more nutrients, which reflected on the higher plant growth rate Sathiyaraj (2010).

The Similar findings of higher nutrient uptake with drip fertigation over soil application of nutrients were also reported by Veeraputhiran (2000) in hybrid cotton. Jayakumar et al., (2014) reported that drip fertigation in cotton with 150 per cent recommended dose of N, P, $\mathrm{K}$ and biofertigation was significantly superior in nutrient uptake with the highest $\mathrm{N}, \mathrm{P}$ and $\mathrm{K}$ uptake of $110.9,28.2$ and $110.6 \mathrm{~kg} \mathrm{ha}^{-1}$ at 120 DAS, respectively. Similar results with drip biofertigation at 125 per cent RDF through water soluble fertilizer with Azophosmet and $1 \%$ PPFM foliar spray recorded higher nitrogen uptake founded by (Jeyajothi et al., 2017). Bharathi et al., (2017) concluded that the nutrient uptake of bhendi was increased with $75 \% \mathrm{RDF}$ of $\mathrm{N}, \mathrm{P}, \mathrm{K}$ fertilizer along with single dose of microbial consortium as a biofertigation has significantly increased the $\mathrm{N}, \mathrm{P}, \mathrm{K}$ uptake in bhendi.

\section{Yield performance of greengram with drip biofertigation}

The data regarding significantly highest yield (Table 3) and yield attributing characters (Table 2) viz., number of pods plant ${ }^{-1}$, number of seeds pod $^{-1}$, test weight $(\mathrm{g})$, Seed yield $(\mathrm{kg}$ $\left.\mathrm{ha}^{-1}\right)$ and haulm yield $\left(\mathrm{kg} \mathrm{ha}^{-1}\right)$ were registered with combined application of liquid biofertilizers and mineral fertilizers with drip fertigation in treatment $\mathrm{T}_{6}(100 \% \mathrm{RDF}+$ LBBF drip fertigation) (Fig. 1-6). 
Table.1 Influence of different formulations of biofertilizers application on nutrient uptake of greengram at harvesting stage

\begin{tabular}{|l|c|c|c|}
\hline \multicolumn{1}{|c|}{ Treatments } & $\mathrm{N}\left(\mathrm{kg} \mathrm{ha}^{-1)}\right.$ & $\mathrm{P} \mathrm{kg} \mathrm{ha}{ }^{-1)}$ & $\mathrm{K}\left(\mathrm{kg} \mathrm{ha}^{-1)}\right.$ \\
\hline $\mathrm{T}_{1}: 100 \% \mathrm{RDF}$ & 45.80 & 18.17 & 41.77 \\
\hline $\mathrm{T}_{2}: 100 \% \mathrm{RDF}+$ CBBF Seed treatment & 56.27 & 23.77 & 47.87 \\
\hline $\mathrm{T}_{3}: 100 \% \mathrm{RDF}+$ CBBF Soil treatment & 53.60 & 20.77 & 45.60 \\
\hline $\mathrm{T}_{4}: 100 \% \mathrm{RDF}+$ LBBF Seed treatment & 58.10 & 24.10 & 49.77 \\
\hline $\mathrm{T}_{5}: 100 \% \mathrm{RDF}+$ LBBF Soil treatment & 52.23 & 21.03 & 46.07 \\
\hline $\mathrm{T}_{6}: 100 \% \mathrm{RDF}+$ LBBF Drip fertigation & 62.23 & 26.60 & 51.33 \\
\hline $\mathrm{T}_{7}: 100 \% \mathrm{RDF}+$ LCBF Seed treatment & 53.27 & 21.23 & 47.87 \\
\hline $\mathrm{T}_{8}: 100 \% \mathrm{RDF}+$ LCBF Soil treatment & 50.60 & 19.80 & 45.43 \\
\hline $\mathrm{T}_{9}: 100 \% \mathrm{RDF}+$ LCBF Drip fertigation & 54.37 & 23.53 & 46.80 \\
\hline $\mathrm{T}_{10} \mathrm{Control}:$ Only biofertilizers & 41.30 & 16.50 & 43.33 \\
\hline $\mathrm{SE}(\mathrm{m})$ & $\mathbf{2 . 9 1}$ & $\mathbf{1 . 3 9}$ & $\mathbf{1 . 4 8}$ \\
\hline $\mathrm{CD}(\mathrm{P}=0.05)$ & $\mathbf{8 . 7 1}$ & $\mathbf{4 . 1 7}$ & $\mathbf{4 . 4 3}$ \\
\hline $\mathrm{CV}$ & $\mathbf{9 . 5 4}$ & $\mathbf{1 1 . 2 1}$ & $\mathbf{5 . 5 0}$ \\
\hline
\end{tabular}

Table.2 Influence of different formulations of biofertilizers application on yield attributing characters of greengram at harvest stage

\begin{tabular}{|l|c|c|c|}
\hline \multicolumn{1}{|c|}{ Treatments } & $\begin{array}{c}\text { No. of pods } \\
\text { plant }^{-1}\end{array}$ & $\begin{array}{c}\text { No. of Seeds } \\
\text { pod }^{-1}\end{array}$ & $\begin{array}{c}\text { Test weight of } \\
\text { seeds }(\mathrm{g})\end{array}$ \\
\hline $\mathrm{T}_{1}: 100 \% \mathrm{RDF}$ & 11.67 & 10.33 & 29.40 \\
\hline $\mathrm{T}_{2}: 100 \% \mathrm{RDF}+$ CBBF Seed treatment & 16.67 & 11.00 & 37.30 \\
\hline $\mathrm{T}_{3}: 100 \% \mathrm{RDF}+$ CBBF Soil treatment & 14.33 & 11.00 & 36.20 \\
\hline $\mathrm{T}_{4}: 100 \% \mathrm{RDF}+$ LBBF Seed treatment & 17.33 & 12.00 & 37.80 \\
\hline $\mathrm{T}_{5}: 100 \% \mathrm{RDF}+$ LBBF Soil treatment & 14.67 & 12.00 & 36.30 \\
\hline $\mathrm{T}_{6}: 100 \% \mathrm{RDF}+$ LBBF Drip fertigation & 19.67 & 13.00 & 38.77 \\
\hline $\mathrm{T}_{7}: 100 \% \mathrm{RDF}+$ LCBF Seed treatment & 14.67 & 11.00 & 36.50 \\
\hline $\mathrm{T}_{8}: 100 \% \mathrm{RDF}+$ LCBF Soil treatment & 13.33 & 10.33 & 31.50 \\
\hline $\mathrm{T}_{9}: 100 \% \mathrm{RDF}+$ LCBF Drip fertigation & 16.00 & 11.67 & 37.00 \\
\hline $\mathrm{T}_{10}$ Control : Only biofertilizers & 10.00 & 8.00 & 22.30 \\
\hline $\mathrm{SE}(\mathrm{m})$ & $\mathbf{1 . 1 2}$ & $\mathbf{0 . 6 7}$ & $\mathbf{0 . 8 7}$ \\
\hline $\mathrm{CD}(\mathrm{P}=0.05)$ & $\mathbf{3 . 3 7}$ & $\mathbf{2 . 0 2}$ & $\mathbf{2 . 6 1}$ \\
\hline $\mathrm{CV}$ & $\mathbf{1 3 . 1 4}$ & $\mathbf{1 0 . 6 2}$ & $\mathbf{4 . 4 1}$ \\
\hline
\end{tabular}


Table.3 Influence of different formulations of biofertilizers application on seed yield and haulm yield of greengram

\begin{tabular}{|l|c|c|c|c|}
\hline \multicolumn{1}{|c|}{ Treatments } & $\begin{array}{c}\text { Seed yield } \\
\left(\mathrm{kg} \mathrm{ha}^{-1}\right)\end{array}$ & $\begin{array}{c}\text { Per cent } \\
\text { increase } \\
\text { over RDF } \\
(\%)\end{array}$ & $\begin{array}{c}\text { Haulm yield } \\
\left(\mathrm{kg} \mathrm{ha}^{-1}\right)\end{array}$ & $\begin{array}{c}\text { Per cent } \\
\text { increase } \\
\text { over RDF } \\
(\%)\end{array}$ \\
\hline $\mathrm{T}_{1}: 100 \% \mathrm{RDF}$ & 0821.67 & - & 1980.23 & - \\
\hline $\mathrm{T}_{2}: 100 \% \mathrm{RDF}+$ CBBF Seed treatment & 0945.70 & 15.09 & 2450.20 & 23.73 \\
\hline $\mathrm{T}_{3}: 100 \% \mathrm{RDF}+$ CBBF Soil treatment & 0875.50 & 06.55 & 2310.20 & 16.66 \\
\hline $\mathrm{T}_{4}: 100 \% \mathrm{RDF}+$ LBBF Seed treatment & 0960.77 & 16.83 & 2506.70 & 26.32 \\
\hline $\mathrm{T}_{5}: 100 \% \mathrm{RDF}+$ LBBF Soil treatment & 0880.23 & 07.08 & 2350.07 & 18.48 \\
\hline $\mathrm{T}_{6}: 100 \% \mathrm{RDF}+$ LBBF Drip fertigation & 1019.50 & 23.93 & 2543.50 & 28.16 \\
\hline $\mathrm{T}_{7}: 100 \% \mathrm{RDF}+$ LCBF Seed treatment & 0890.20 & 08.29 & 2380.57 & 20.17 \\
\hline $\mathrm{T}_{8}: 100 \% \mathrm{RDF}+$ LCBF Soil treatment & 0850.23 & 03.45 & 2256.97 & 13.83 \\
\hline $\mathrm{T}_{9}: 100 \% \mathrm{RDF}+$ LCBF Drip fertigation & 0930.80 & 13.20 & 2420.23 & 22.00 \\
\hline $\mathrm{T}_{10} \mathrm{Control}:$ Only biofertilizers & 0721.77 & - & 1750.23 & - \\
\hline $\mathrm{SE}(\mathrm{m})$ & $\mathbf{2 6 . 3 2}$ & - & $\mathbf{7 2 . 6 5}$ & - \\
\hline $\mathrm{CD}(\mathrm{P}=0.05)$ & $\mathbf{7 8 . 8 2}$ & - & $\mathbf{2 1 7 . 5 5}$ & - \\
\hline $\mathrm{CV}$ & $\mathbf{5 . 1 2}$ & - & $\mathbf{5 . 4 8}$ & - \\
\hline
\end{tabular}

Fig.1 Influence of different formulations of biofertilizers application on nutrient uptake of greengram at harvesting stage

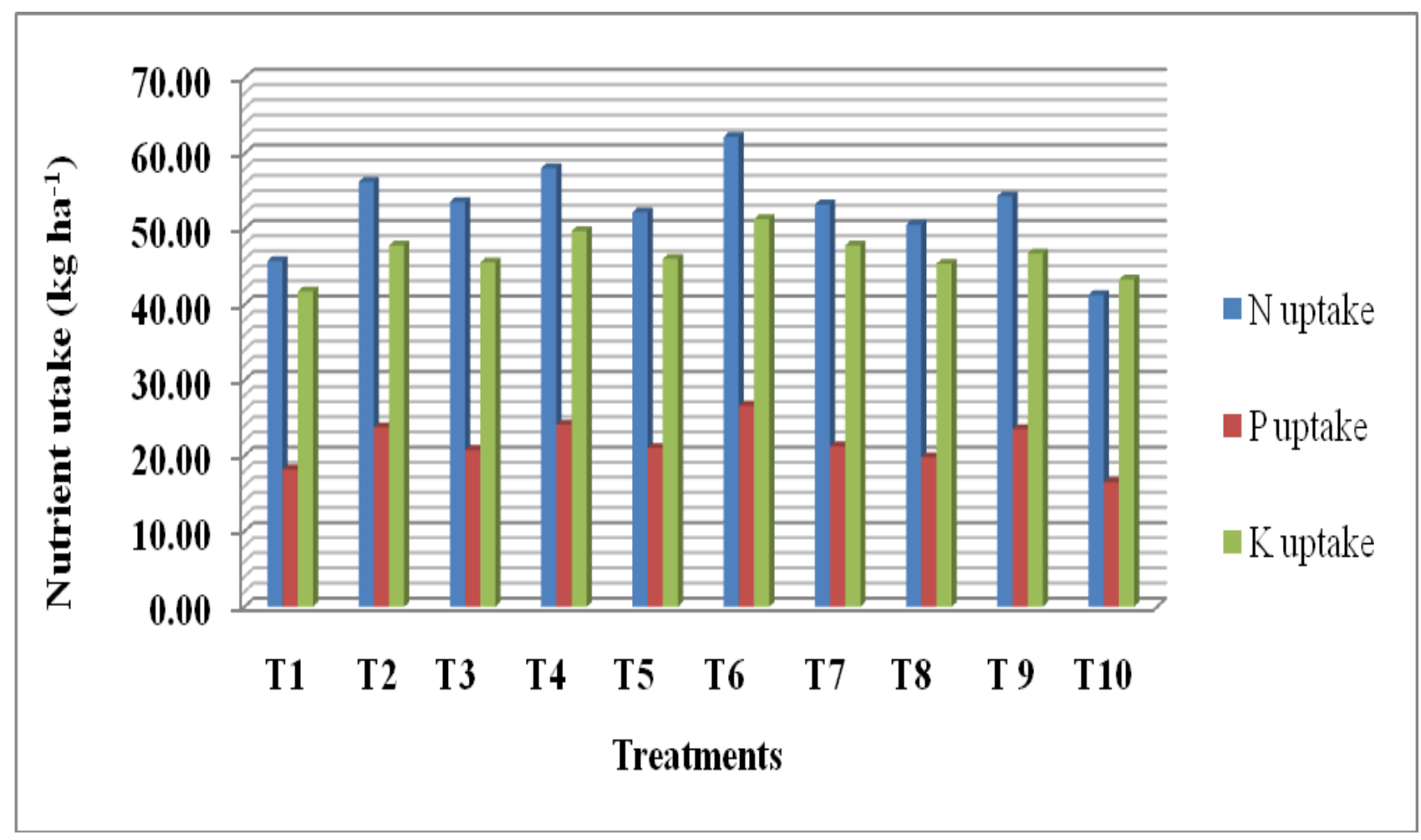


Fig.2 Influence of different formulations of biofertilizers application on number of pods plant ${ }^{-1}$ of greengram at harvest stage

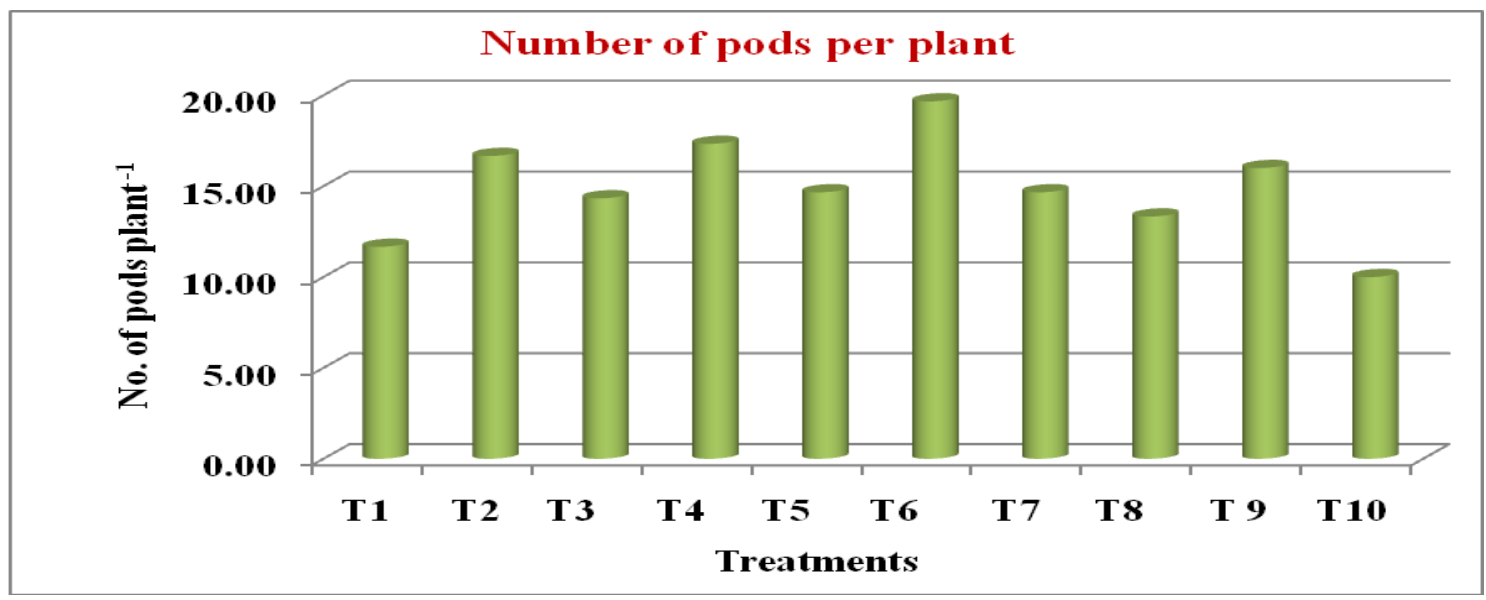

Fig.3 Influence of different formulations of biofertilizers application on number of pods plant ${ }^{-1}$ of greengram at harvest stage

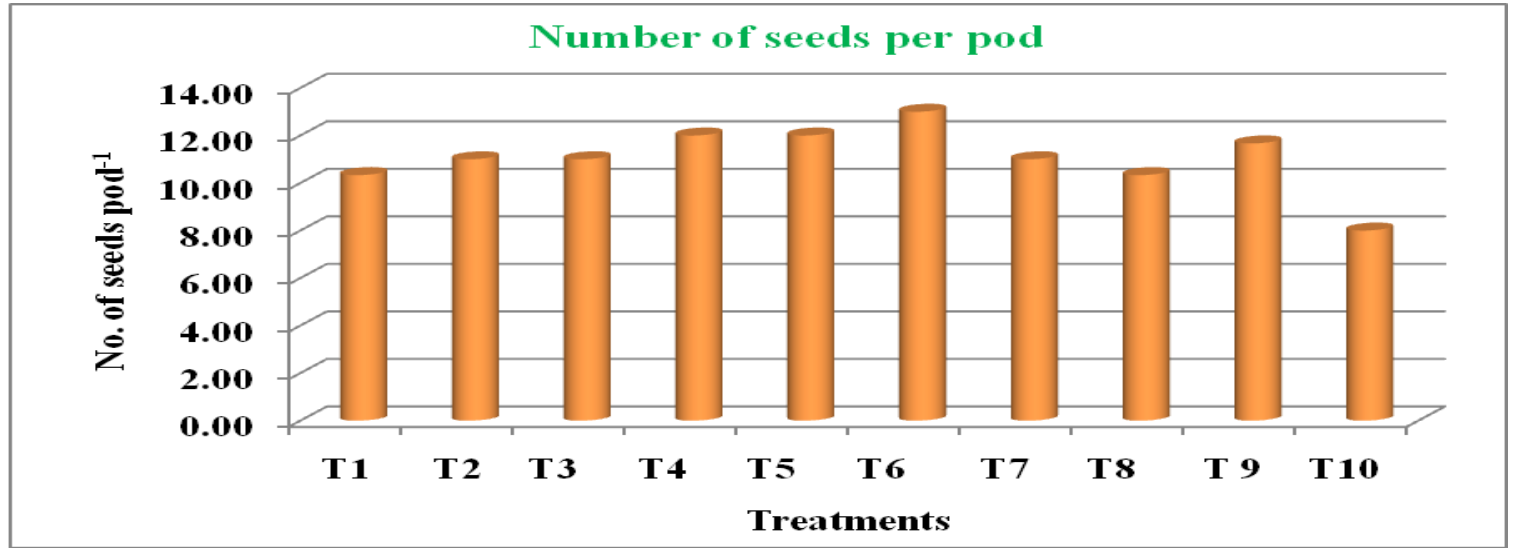

Fig.4 Influence of different formulations of biofertilizers application on test weight $(\mathrm{g})$ of greengram at harvest stage

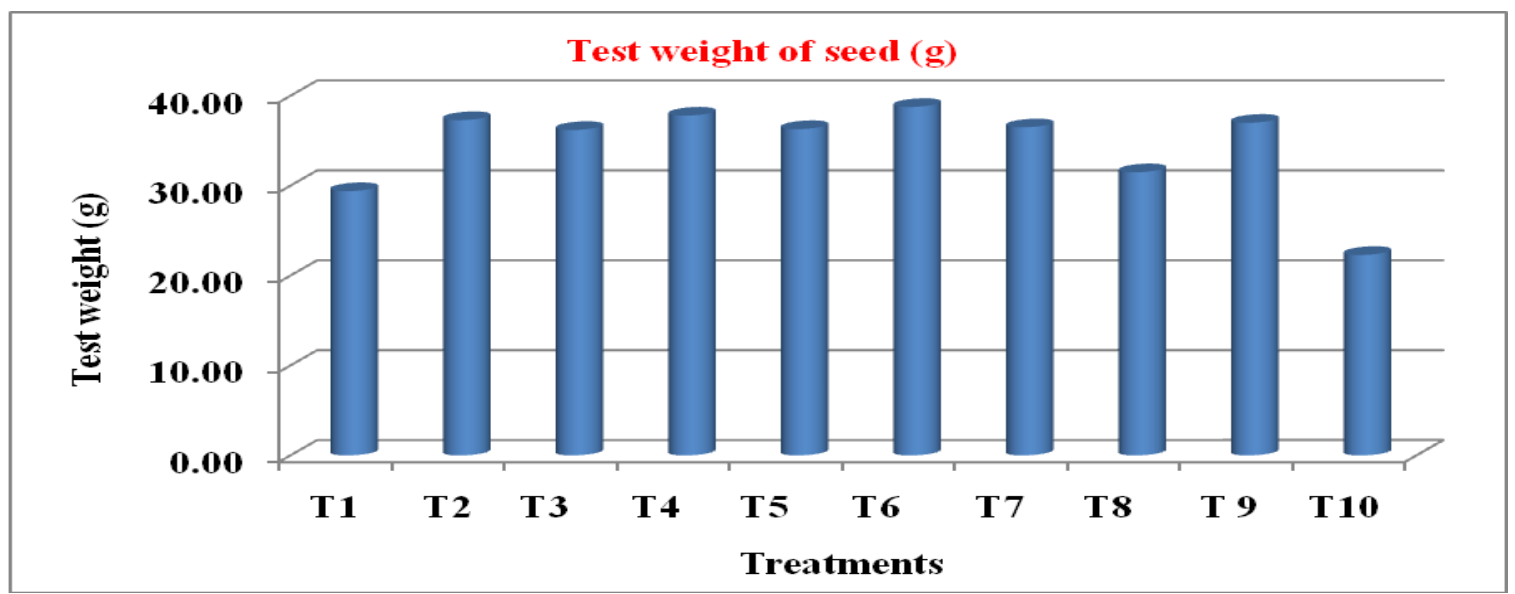


Fig.5 Influence of different formulations of biofertilizers application on seed yield of greengram

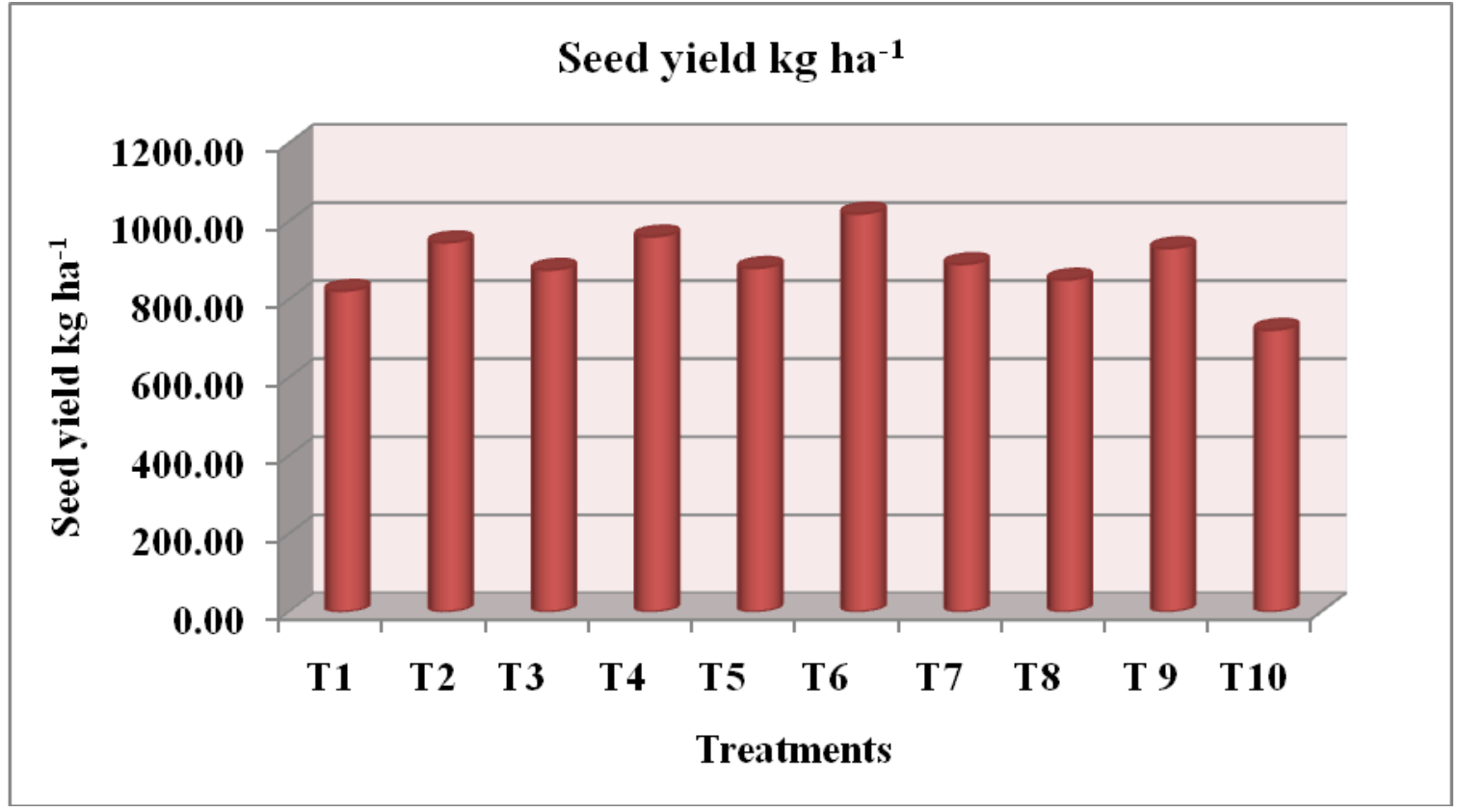

Fig.6 Influence of different formulations of biofertilizers application on haulm yield of greengram

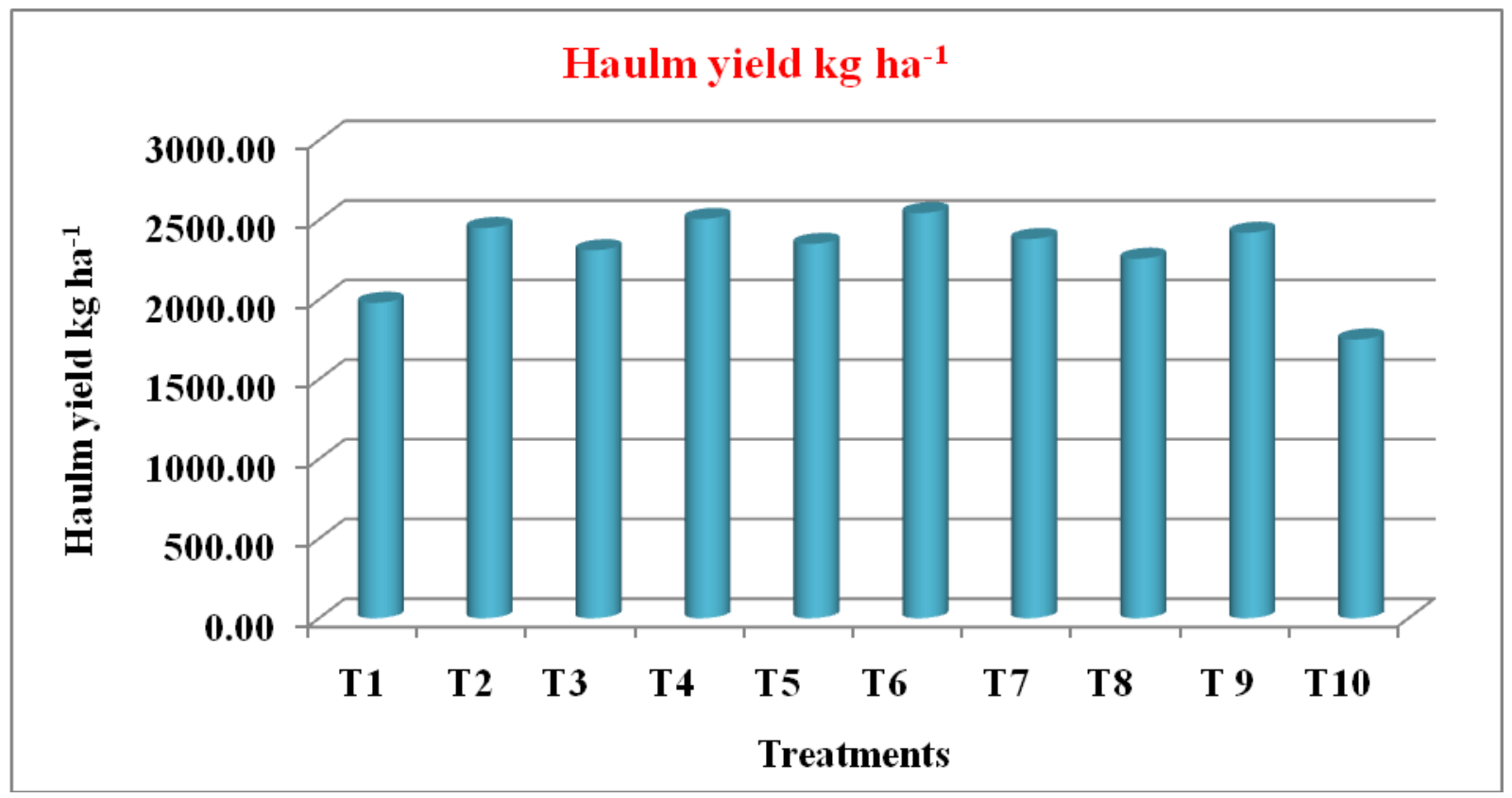

It might be due to biofertigation can precisely deliver the bio inoculants in the root zone (Gomathy et al., 2008). It is an added advantage whereas microbial inoculants are supplied through biofertigation as it has more water use efficiency and fertilizer use efficiency, quality etc. Effective microorganisms and can also applied in the field along with inorganic materials (Hussain et al., 1999). Liquid formulations of microbial 
resources could be a potential organic input for precision farming, which can be easily delivered through fertigation system for effective colonization of root zone of crop plants.

The fertigation with liquid based biofertilizers and $100 \%$ RDF resulted in higher availability of all three major nutrients (N, P and $\mathrm{K}$ ) in the soil solution, which led to higher uptake and better translocation of assimilates from source to sink, thus in turn increased the yield. Similar linear response was obtained in long duration pigeonpea under drip fertigation by Vimalendren and Latha (2014).

The above results were in line with Senthilkumar et al., (2014) $100 \%$ recommended dose of fertilizers through fertigation (RDFTF) with $300 \mathrm{~g}$ of consortium of biofertilizers $(\mathrm{CBF})$ recorded significantly higher yield attributing characters. The similar results were obtained by using biofertigation in different crops found by Gomathy et al., (2008) reported that application of $150 \%$ of recommended NPK as drip fertigation combined with biofertigation of liquid formulation of azophosmet was significantly better and increased the growth parameters and yield attributes of cotton.

Jayakumar et al., (2014) reported that application of 150 per cent RDF as drip fertigation combined with biofertigation of liquid formulation of azophosmet @ $250 \mathrm{ml}$ (1012 cells $\mathrm{ml}^{-1}$ ) $\mathrm{ha}^{-1}$ registered the highest seed cotton yield of $3395 \mathrm{~kg} \mathrm{ha}^{-1}$. Bharathi et al., (2017) conducted a field trail experiment to study the effect of biofertigation on plant growth under precision farming system in Bhendi ( $\mathrm{COBH} 1)$. The result suggested the positive influence of $75 \% \mathrm{RDF}$ of NPK + Microbial consortium application with single time (60 lit $\left.\mathrm{ha}^{-1}\right)$ on delivery of inoculants viz., Azospirillum (5.96 $\pm 0.12 \log$ cells $\left.\mathrm{ml}^{-1}\right)$,
Bacillus $\left(7.00 \pm 0.12 \mathrm{ml} \log\right.$ cells $\left.\mathrm{ml}^{-1}\right)$ and Pseudomonas $\left(7.30 \pm 0.02 \mathrm{log}\right.$ cells $\left.\mathrm{ml}^{-1}\right)$, plant growth and $10 \%$ increased yield over conventional method. Jeyajothi et al., (2017) founded similar results in pigeonpea.

Precision farming is one among the integrated management approaches of agriculture, which include fertigation and combined practice of organic and inorganic farming to get highest yield and to minimize the cost of farming. Fertigation system of precision farming is considered as effective delivery of nutrients exactly at the root zone of crop, which minimize the loss as well as reduce the environmental hazards caused by the chemicals. This technology ensures the fertilizer use effectively to a greater extent. Biofertigation can precisely deliver the bio inoculants in the root zone (Gomathy et al., 2008). It is an added advantage whereas microbial inoculants are supplied through biofertigation as it has more water use efficiency and fertilizer use efficiency, quality etc. Effective microorganisms can also applied in the field along with inorganic materials (Hussain et al., 1999).

The results clearly confirmed that bio fertigation could be an effective system which increased the ultimate output of yield.

\section{Abbreviations}

RDF: Recommended dose of NPK fertilizers

LBBF: Liquid based biofertilizers

CBBF: Carrier based biofertilizers

LCBF: Liquid culture based biofertilizers

\section{References}

Bharathi, J., Balachander, D., Kumar, K and Narayanan, R. 2017. Evaluation of new microbial consortium through biofertigation for precision farming of bhendi (cobh 1). International Journal 
of Medical Sciences \& Pharmaceutical

Research. 1(1): 15-24.

Brahmaprakash, G.P and Sahu, P.K. 2012. Biofertilizers for Sustainability. Journal of Indian Institute of Science. 92: 37-62.

Chandra, K., Greep, S., Ravindranath, P and Srivathsa, R.S.H. 2005. Liquid Biofertilizers (Government of India, Ministry of Agriculture, Department of Agriculture and Cooperation, Regional Center for Organic Farming). Regional Director, Regional Center for Organic Farming, Bangalore.

Gomathy, M., Sathya, P.D., Thangaraju, M., Sundaram, S.P and Manicka, S.P. 2008. Impact of biofertigation of Azophosmet on cotton yield under drip irrigation. Research Journal of Agriculture and Biological Sciences. 4(6): 695-699.

Hussain, T., Javaid, T., Parr, J.F., Jilani, G and Haq, M.A. (1999). Rice and wheat production in Pakistan with effective microorganism. Am. J. Alt. Agric. 1: 3036.

Jayakumar, M., Surendran, U., Manickasundram, P. 2014. Drip fertigation effects on yield, nutrient uptake and soil fertility of Bt Cotton in semi-arid tropics. International Journal of Plant Production. 8 (3): 1-16.

Jeyajothi, R and Pazhanivelan, S. 2017. Dry matter, nutrient uptake and yield of short duration pigeon pea (Cajanus cajan L.) varieties under drip fertigation system. International Journal of
Current Microbiology and Applied Sciences. 6 (11): 3958-3965.

Palanisami, K.K., Mohan, K. R., Kakumanu and Raman, S. 2012. Spread and economics of micro irrigation in India: Evidence from different states. 258-266.

Rishi, N. 2009. Significant plant virus diseases in India and a glimpse of modern disease management technology. J. Gen. Plant Pathol. 75: 118.

Sathiyaraj, M. 2010. Study on the influence of irrigation regimes and fertigation levels on sugarcane under subsurface drip fertigation system. Ph.D. Thesis. Tamil Nadu Agric. Univ., Madurai.

Senthilkumar, M., Ganesh, S., Paneerselvam, $P$ and Srinivas, K. 2014. Influence of fertigation and consortium of biofertilizer on photosynthesis, chlorophyll content yield parameters and yield of banana cv. robusta (AAA). Plant Archives. 14(1): 387-391.

Singh, N., Singh, H and Nagarajan, P. 2013. Development of SSR markers in mung bean, Vigna radiata (L.) Wilczek using in silico methods. J. crop weed. 9: 6974.

Veeraputhiran, R. 2000. Drip fertigation studies in hybrid cotton. Ph.D. Thesis, Tamil Nadu Agric. Univ. Coimbatore.

Vimalendran. L and K.R. Latha. 2014. Yield, water use and water use efficiency of pigeonpea [Cajanus cajan (L.) Millsp.] under drip fertigation system. JANS. 6(1): 457-462.

\section{How to cite this article:}

Shravani K., S. Triveni, P. C. Latha, V. Ramulu, M. Tejashree and Damodharachari, K. 2019. Influence of Biofertilizers under Drip Fertigation System on NPK Uptake and Yield Performance of Greengram (Vigna radiata L.). Int.J.Curr.Microbiol.App.Sci. 8(05): 24092417. doi: https://doi.org/10.20546/ijcmas.2019.805.285 